\title{
School Libraries and Use of Social Media to Interact With Students-A Case Study With Reference to Kendriya Vidyalaya Libraries, Government and Private School Libraries in North East
}

\author{
Anup Singh \\ B.A.M.A. Eng, Pol. Sc., B. Ed, BLIS, MLIS, M. Phil, UGC NET (LIS) \\ Librarian, K.V.Nadaun, VPO+Tehsil:Nadaun, Distt: Hamirpur (H.P)782447, India
}

\begin{abstract}
Social media is helpful for stirring up interaction among users. The number of libraries which adopt Social Media is increasing. However, user engagement is low on many libraries. Existing research mainly focuses on the ways Social Media used in libraries and the librarians or users' attitudes towards libraries using Social Media. Little research has been done on how to use Social Media to interact with school library users effectively. This study focuses on the interactions between libraries and users on libraries' Facebook, Twitter. Four types of interactions are examined ,including knowledge sharing, information dissemination, communication and knowledge gathering. A mixed method is applied in this study: quantitative results, generated from the analysis on around 1500 posts sampled from 40 school libraries' Social Media are incorporated with qualitative results concluded from the interviews with 10 librarians. The study finds that among the four types of interactions, knowledge sharing attracts the largest volume of users' responses on libraries' Social Media. The study's investigation on the differences of Facebook-like and Twitter-like Social Media and those between different Kendriya Vidyalaya Libraries and other Government School, Railway School and Private School libraries of the Nagaon District of Assam on using Social Media suggest that in order to improve the efficiency of interacting with users on social media, there are necessities for libraries to coordinate different types of social media and take the properties of their communities under consideration.
\end{abstract}

Keywords: Library, social media, user engagement, interaction

\section{Introduction}

Social Media provide an innovative and effective way of connecting users. Features of social media enable users to generate interpersonal connections based on common grounds. Social Media, such as Friedster, LinkedIn, Myspace and Facebook, set up personal communities, allow users to make persistent comments on the profile of their friends and send private messages. These features make social media excellent in initiating interaction among users. The number of libraries which adopt social media is increasing. In a survey, it is found that social media was only adopted by a few academic libraries. Facebook and Twitter have become the most popular Web 2.0 applications in libraries.

However, school students"e attitudes towards using social media to enhance and encourage interaction for educational purposes are not very supportive. Students still deem that social media are used mainly for communicating with friends. Students do not use Facebook to contact faculties and do not expect to interact with faculty through social media. Students ${ }^{\text {ee }}$ engagement is low on libraries "e using social media. It is observed that there were only few responses from users on a number of libraries" fan pages. Libraries" Twitter accounts only got a few followers. To address the challenge of engaging users on libraries" social media and to provide well informed suggestions, this study focuses on the interactions between school librarians and students on social media.

\section{Literature Review}

The use of social media in libraries

Social Media provides libraries with an innovative and effective way of connecting with users (O'Dell, 2010). Librarians make use of social media with the purpose of "begin part of their communities" (De Rose et al.,2007), or promoting libraries" services and events (Charnigo \& Bamett-Ellis, 2007; Hendix,Chiarella, Hasman Murphy, \& Zafron 2009). There are libraries which use Twitter to connect themselves with important information sources (Milstein, 2009).Research found that Facebook are engaging to college students when applied in libraries(Mack, Behler, Roberts \& Rimland, 2007). According to Graham 92009), Facebook had facilitated the development of professional relationship in and beyond libraries. Despite the increasing adoption of social media by libraries, user engagement on libraries"e social media is low. Libraries"e Twitter accounts only got a few followers (Sturat,2010), and users" input is very low on libraries" Facebook fan pages (Jacobson, 2011). There are several factors that may hinder libraries" social media interacting with their users. Researchers suggested that the concerns of privacy from users (Chu et al., 2008; De Rosa et al., 2007), and updating information in low frequency (Stuart, 2010) have negative impact on the effectiveness of social media in facilitating interactions. Besides, Ram"s study (2011) on a university showed that both students and faculty displayed a high awareness of Facebook and Twitter, but users had a low awareness of the university library"s presence on facebook. Ram"s study suggests that low user engagement could be attributed to inadequate promotion. Existing studies that involve user 


\section{International Journal of Science and Research (IJSR) \\ ISSN (Online): 2319-7064}

Index Copernicus Value (2013): 6.14 | Impact Factor (2014): 5.611

engagement just examine the total number of followers or the total number of user responses (Jacobson, 2011; Stuart,2010), which are too conclusive to reveal how libraries can use social media to engage users.

\section{Interaction Types on Social Media}

In online social media, information-flow is n-ways, generating different types of interactions. Relevant researches have been done on four types of interactions: one-to- many knowledge sharing (Harinarayana \& Raju, 2010), one-to-many information dissemination (Ram et al., 2011), one-to-one communication (Romero, 2011) and many-to-one knowledge gathering (O'Dell, 2010). First, by exploiting their information resources and professionals, libraries create knowledge and share it with communities (MacAdam, 1998). Knowledge sharing is an important aspect for libraries in utilizing social media, since libraries play an important role in knowledge sharing (MacAdam, 1998). To achieve knowledge sharing, technical and systematic infrastructure is needed, "making knowledge available to others who need it" (Seonghee \& Boryung, 2008). Libraries act as the backend of their media, provide organized resources on social networking platforms, stimulate useres participation, and fulfill the dynamics of knowledge sharing (Harinarayana \& Raju, 2010). Facebook and Twitter are applied by libraries to build up academic networks, "catalyzing the exchange ofknowledge" (Ayu \& Abrizah, 2011; Nicholas, Watkinson, Rowlands, \& Jubb, 2011).

Secondly, disseminating information to users is a critical function of Web 2.0 technology. Its weight in measuring the effectiveness of libraries ${ }^{\text {ee }}$ SNSs is comparable with knowledge sharing (Ram et al., 2011). Most information being disseminated through SNSs are about business in the libraries. Kim and Abbas (2010) reported that 55 libraries in Massachusetts Institute of Technology made announcements on Twitter, including those about resources, workshops, courses, etc. Compared with other Web 2.0 technologies, Facebook and Twitter are more capable in syndicating and disseminating information (Cahill, 2009). The concise style of text mitigates the impact of information overload, making social media excellent for information dissemination (Kim \& Abbas, 2010).

Thirdly, communication, including dialogues and comments, is one of the most important areas in measuring the effectiveness of social media (Romero, 2011). Social media is efficient for communication. Research finds that low selfdisclosure on SNS make it easier for users to launch conversations with acquaintances (McElvain \& Smyth, 2006). Besides, due to the concise format and informal tones, social media is more likely to stir up interactions between users than the other non-social networking Web 2.0 technologies, such as blogs and wikis (Romero, 2011). Scholars concluded that social media can advance communication in quantity and may improve in quality (Boyd \& Ellison, 2007; Ito et al., 2008). However, it has been observed that extracting responses from users in public networks does not seem as easy as in personal social circles (Burton \& Soboleva, 2011; Chen, Maxwell, Chu, Li, \& Tang, 2011).
Fourthly, social media are good at knowledge gathering that they have been utilized in research of social sciences to gather professional knowledge and the responses from research objects (Poynter, 2010). With millions of users, social media offers opportunities for libraries to reach out to communities and gather knowledge from the interaction between librarians and users (O'Dell, 2010). Users can help create new library services by contributing their knowledge through online network (Casey \& Savastinuk, 2006).To find out how libraries can facilitate the interactions with users on their social media, this study examined user engagement under the four types of interaction. The posts on social media are grouped under the four interaction types (see Table 2), formulating a scheme to classify the interaction activities on libraries ${ }^{\text {ee }}$ social media.

\section{Research Gap}

Extant research mainly focuses on the ways of social media used in libraries and the attitudes of librarians or users towards libraries using social media. Little research has focused on the interaction between school libraries and users. This study focused on interaction on school libraries ${ }^{\text {ee }}$ social media and explores different types of interactions. In addition, existing studies are restricted to either Facebook or Twitter only at college and university level. To expand the scope of study, this research includes use of Facebook, Twitteres at school libraries in India. The differences of interactions between libraries and users on Social media were compared. Comparisons were also conducted between Kendriya Vidyalaya Libraries and Government + Private school libraries in using social media

Facebook had over 950 million active users by 2013 (Facebook, 2013). Twitter just released that it has garnered 150 million active users who "actually say something" (McMillan, 2013). Sina Weibo, so-called Chinaes Twitter, is a leading SNS in China, which has surpassed any others and garnered $57 \%$ of China's microblog users (Loretta, 2011).With these comparisons, this study is expected to provide insights for different libraries about users'

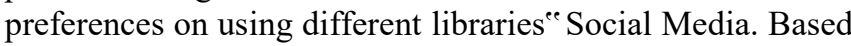
on the research gap, this paper tries to answer four research questions:

Q1: How do school libraries interact with users on social media?

Q2: Which type of interaction is most engaging to library users?

Q3: What are the differences among Facebook and Twitter regarding the interactions between libraries and users?

Q4: What are the differences between Kendriya Vidyalaya Libraries and Government + Private School libraries when using social media to interact with users? 


\section{International Journal of Science and Research (IJSR) ISSN (Online): 2319-7064 \\ Index Copernicus Value (2013): 6.14 | Impact Factor (2014): 5.611}

\section{Research Method}

This study used a mixed method, in which quantitative and qualitative data were incorporated to answer the research questions.

\section{Sampling}

The samples in this study were a total of 40 libraries of Kendriya Vidyalaya Sangthan, Government School and Private School of India. In order to capture diverse contents and observe various user responses on social media, the participating libraries were required to have a substantial amount of existing resources and library users. Therefore, libraries in Kendriya Vidyalaya Sangthan, Government School and Private School that are up to Sr. Sec level are selected. The social media studied in this paper, covered Facebook and Twitter. Table 1 summarizes the constitution of our sample. Among 40 libraries, ten libraries agreed to participate in interviews. During sampling, it was found that no Government School library was using social media in north east of India; and other than Twitter, Facebook is commonly used among libraries in Private Schools.

Table 1: The sampled libraries in the study

\begin{tabular}{|c|c|c|c|c|c|}
\hline Region & $\begin{array}{c}\text { Social } \\
\text { Media }\end{array}$ & $\begin{array}{c}\text { Kendriya } \\
\text { Vidyalaya } \\
\text { Libraries }\end{array}$ & $\begin{array}{c}\text { Government } \\
\text { School } \\
\text { Libraries }\end{array}$ & $\begin{array}{c}\text { Private } \\
\text { School } \\
\text { Libraries }\end{array}$ & Total \\
\hline $\begin{array}{c}\text { Kendriay } \\
\text { Vidyalaya } \\
\text { Sangthan }\end{array}$ & Facebook & 15 & 2 & 3 & 20 \\
\hline & Twitter & 15 & 3 & 2 & 20 \\
\hline Subtotal & & 30 & 5 & 5 & 40 \\
\hline
\end{tabular}

Note: All the samples for Government and Private School Library are from North East Region of India.

\section{Data Collection and Analysis}

Posts were sampled from the 40 libraries ${ }^{\text {ee }}$ social media, including contents posted by libraries or users. Considering the calendars of schools, the time of sampled posts ranged from May 2013 to May 2014. And 10 posts were sampled in each month randomly. The number of user responses to each sampled post was registered which contained two parts: the number of comments from users and the number of sharings (that is the number of ,like ${ }^{e c}$ on Facebook, ,retweet ${ }^{\text {ee }}$ on Twitter or ,forward"). Totally, 1753 posts were harvested. The sampled posts were coded, according to their interaction types (see Table 2). The four interaction types are not exclusive to one another, which means one post could contain more than one types of interactions. There were two coders involved in coding the sampled posts, conducting the coding independently. Before and during the coding, coders discussed the definitions and meanings of the terms in Table 2 , in order to reconcile the differences in understanding. The inter coder reliability is measured in Cohen 's Kappa and the minimum acceptable level is set at 0.90 (Lombard, SnyderDuch, \& Bracken, 2002). Among the studied libraries, 10 have participated in semi-structured interviews through telephone, in which the librarians were asked to share their experience and perceptions on using social media. The sampled posts were analyzed quantitatively. And the interviews with librarians were analyzed qualitatively. To achieve more robust answers to the research questions, the quantitative results generated from the analysis on sampled posts were supplemented by librarians ${ }^{\text {ee }}$ perceptions and experience in using social media that were concluded from interviews. When coding was finished, the codes and posts were exported from NVivo 8.0 into PASW Statistics 18.0 for quantitative analysis. ANOVA analysis and t-test were conducted on the data. Statistical significance was set at $\mathrm{p}<0.05$. Dialogues in the interviews were coded according to the questions in the interview schedule (see Appendix) on Nvivo 8.0.

Table 2: Four interaction types on libraries "e social media

\begin{tabular}{|c|c|c|}
\hline Themes & Definition & Sample References \\
\hline $\begin{array}{l}\text { Knowledge } \\
\text { sharing }\end{array}$ & $\begin{array}{l}\text { Librarians or } \\
\text { users share } \\
\text { information } \\
\text { resources with } \\
\text { others }\end{array}$ & $\begin{array}{l}\text { LIBRARY: Learning to read } \\
\text { and write at the Library: } \\
\text { MMM }^{\text {ee }} \text { story MMM, faced } \\
\text { up to a number of personal } \\
\text { challenges before he enrolled } \\
\text { in the MMM Centre for } \\
\text { Reading and Writing. }\end{array}$ \\
\hline \begin{tabular}{|c|} 
Information \\
Dissemination
\end{tabular} & $\begin{array}{l}\text { Updating the } \\
\text { news and } \\
\text { announcement } \\
\text { from libraries. }\end{array}$ & $\begin{array}{l}\text { Library: Calling all teachers! } \\
\text { Free CPD events (15 June } \\
\text { and } 16 \text { June) linked to out } \\
\text { this world: Science Fiction } \\
\text { but not as you know it. } \\
\text { Conference and CPD } \\
\text { www.mmm.mmm } \\
\text { Find out more about } \\
\text { conference and other events } \\
\text { for students and teachers. }\end{array}$ \\
\hline Communication & \begin{tabular}{|c} 
Aimed at \\
individuals, \\
conversations \\
that happen \\
between \\
librarians and \\
users or among \\
users.
\end{tabular} & $\begin{array}{l}\text { Users: Where could I found } \\
\text { our school enrollment in } \\
\text { recent years and the } \\
\text { employment situation? @ } \\
\text { Library: Use internal search } \\
\text { engine on our school library } \\
\text { home page, enter the } \\
\text { advanced search interface } \\
\text { and search employment or } \\
\text { enrollment information. }\end{array}$ \\
\hline $\begin{array}{l}\text { Knowledge } \\
\text { Gathering }\end{array}$ & \begin{tabular}{|c|} 
Harvesting \\
information from \\
individual users \\
for improving \\
library services, \\
academic \\
research, etc.
\end{tabular} & $\begin{array}{l}\text { Library: Tell us why you "ve } \\
\text { used the Library. Your } \\
\text { stories-What does the MMM } \\
\text { Library mean to you? } \\
\text { www.mmm.mmm } \\
\text { DESCRIPTION HERE }\end{array}$ \\
\hline
\end{tabular}

Note: All the words that involve the identities of research participants are changed as MMM; The four interaction type are not exclusive to one another, which mean one post could contained more than one type of interactions.

\section{Findings}

\section{Interactions on libraries' social media}

To find out how libraries interact with users on social media, the sampled posts were summarized in percentage based on their interaction types (see Figure 1). The figure showed that more than half of the sampled posts were information dissemination. Knowledge sharing, accounting for $28.34 \%$ in the sample, was carried out substantially by libraries, though it was not as outstanding as information dissemination. In comparison, the communication between libraries and users was not conducted as frequently as knowledge sharing and information dissemination 


\section{International Journal of Science and Research (IJSR) \\ ISSN (Online): 2319-7064 \\ Index Copernicus Value (2013): 6.14 | Impact Factor (2014): 5.611}

(accounting for $15.46 \%$ ). Finally, knowledge gathering was executed most rarely on libraries ${ }^{e e}$ social media, only accounting

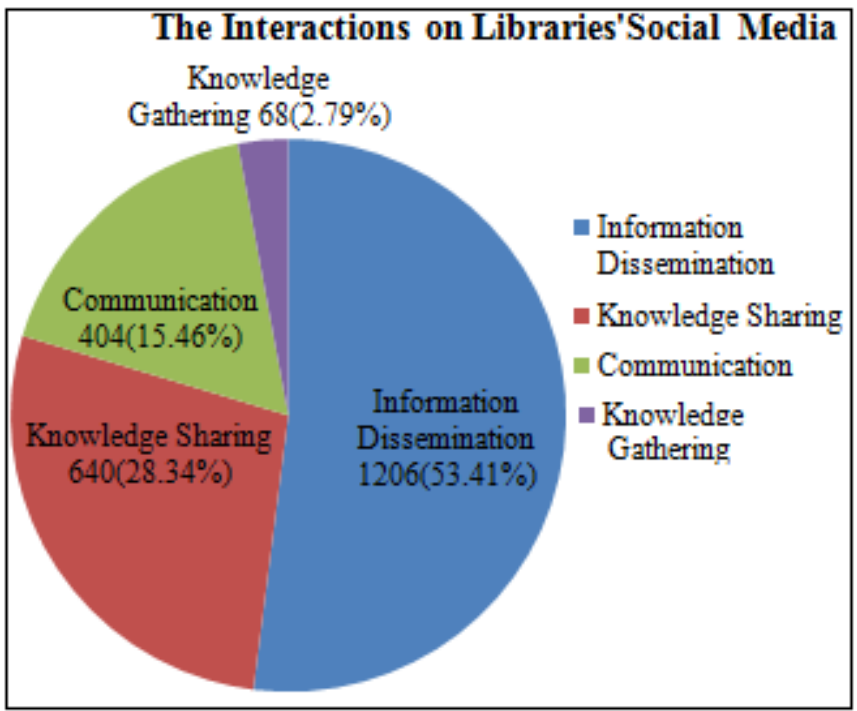

Figure 1: The interactions on libraries ${ }^{\text {ee }}$ Social Media

User engagement under the different types of interaction was explored by comparing the means of user responses among posts of different interaction types. The null hypothesis is that "the means of user responses are not different between posts carrying certain type of interaction and those not carrying that type of interaction." The result reveals that the mean of users responses to posts of knowledge sharing was the highest (see Table 3) $(\mathrm{p}<0.001)$.

Secondly, the means of user responses were comparable between information dissemination and communication. No statistical significance was identified on these two means.

Thirdly, user responses to the posts of knowledge gathering were very fluctuating. Hence, at this moment, the data were unable to tell whether this type of interaction could get more user responses than the others.

Table 3: Mean values of user responses to posts of different interaction types

\begin{tabular}{|c|c|c|c|}
\hline Interaction & Mean \pm Std. Error & $T$ & Sig. \\
\hline Knowledge Sharing & $15.39 \pm 1.30$ & 18.74 & $.000^{*}$ \\
\hline Dissemination & $8.44 \pm 1.05$ & 0.02 & .88 \\
\hline Communication & $9.90 \pm 1.91$ & 2.79 & .095 \\
\hline Knowledge Gathering & $15.17 \pm 7.84 \mathrm{a}$ & 1.43 & .232 \\
\hline
\end{tabular}

Note: AThough the mean value seems high, the analysis fails to identify statistical significance, due to its relatively large standard error; ${ }^{*} \mathrm{p}<0.001$.

Table 4: Mean values of user responses to posts of different interactions on different social media

\begin{tabular}{|c|c|c|c|c|c|}
\hline \multirow{2}{*}{ Region } & \multirow{2}{*}{$\begin{array}{c}\text { Social } \\
\text { Media }\end{array}$} & \multicolumn{4}{|c|}{$\begin{array}{c}\text { Interaction } \\
\text { Mean Std. }\end{array}$} \\
\cline { 3 - 6 } & & $\begin{array}{c}\text { Knowledge } \\
\text { Sharing }\end{array}$ & $\begin{array}{c}\text { Information } \\
\text { Dissemination }\end{array}$ & Communication & $\begin{array}{c}\text { Knowledge } \\
\text { Gathering }\end{array}$ \\
\hline $\begin{array}{c}\text { Kendriya Vidyalaya Sangthan } \\
\text { Libraries }\end{array}$ & Facebook & $21.90 \pm 1.96$ & $4.49 \pm 0.67$ & $20.00 \pm 2.36$ & $15.89 \pm 3.72$ \\
\hline $\begin{array}{c}\text { Government and Private School } \\
\text { Libraries }\end{array}$ & Twitter & $5.26 \pm 2.55$ & $7.90 \pm 2.90$ & $10.73 \pm 2.29$ & $16.89 \pm 9.70 \mathrm{a}$ \\
\hline & Facebook & $12.63 \pm 5.71$ & $14.69 \pm 1.47$ & $2.56 \pm 0.64$ & $1.67 \pm 1.67$ \\
\hline & Twitter & $0.49 \pm 0.11$ & $2.32 \pm 0.23$ & $3.59 \pm 0.472$ & $2.56 \pm 1.89$ \\
\hline
\end{tabular}

Note: The highest means in bold;aThough the mean value seem seems high, the analysis fails to identify statistical significance, due to its relatively large standard error.

\section{Differences between Facebook and Twitter}

The statistical analysis on sampled posts reveals that the capabilities of the four types of interaction in engaging users varied across Facebook, Twitter (seeTable 4). The null hypothesis is that "under one interaction type, the means of user responses have no difference among different social media." As shown in the table, on libraries "e Facebook, knowledge sharing was the most excellent type of interaction in attracting user responses both in Kendriya Vidyalaya Libraries and Government and private School libraries $(p<0.05)$. Communication attained higher user engagement than information dissemination and knowledge gathering on libraries ${ }^{\text {ee }}$ Facebook in Kendriya Vidyalaya Libraries $(\mathrm{p}<0.05)$. However, in Government and private school libraries, communication just got few responses on librariese $^{\text {ee }}$ Facebook. On Twitter, Table 4 showed that communication attained the highest user responses on average $(p<0.05)$. In comparison, information dissemination was moderate in engaging users across the two social media, so does knowledge gathering. Interviewees ${ }^{\text {ee }}$ comments on the differences between Facebook and Twitter were mainly in two aspects: audience and user engagement (see Table 5). All the interviewees from Kendriya Vidyalaya libraries, who are both using Facebook and Twitter, stated that the audience is different between Facebook and Twitter. The main audience of Facebook was the youth while Twitter garnered a wider audience-range, including professionals. They commented that the differences were caused by the different features between Facebook and Twitter, regarding the richness of contents on SNSs, and the designs of their interfaces. However, except one interviewee, the other four interviewees from Kendriya Vidyalaya Libraries reported that their libraries did not treat Twitter and Facebook differently. R7 stated out that basically, the contents they published on Twitter were the same as those published on Facebook. Interviewees from Government and private school libraries are using only one social media. R1, R3 and R5 from Government and private school of North East of India, who use Facebook, got 3 for interviewees from Assam (North East), they were asked to compare Twitter and Facebook-like tool in Government and private school. An impression that users rarely commented on Facebook and

\section{Volume 4 Issue 11, November 2015}




\section{International Journal of Science and Research (IJSR) \\ ISSN (Online): 2319-7064 \\ Index Copernicus Value (2013): 6.14 | Impact Factor (2014): 5.611}

Twitter, but Private School was more likely to click the "like" button. R2 and R4, who used Twitter, did not stress that it was used more in connecting professionals. Rather, like Facebook, it was deemed as a tool used to get close to the youth. And Both R2 and R4 commented that Twitter worked out well in terms of inquiries and comments from users.

Table 5: Librarians ${ }^{e e}$ perceptions on the differences among Facebook and Twitter in the ways of engaging users

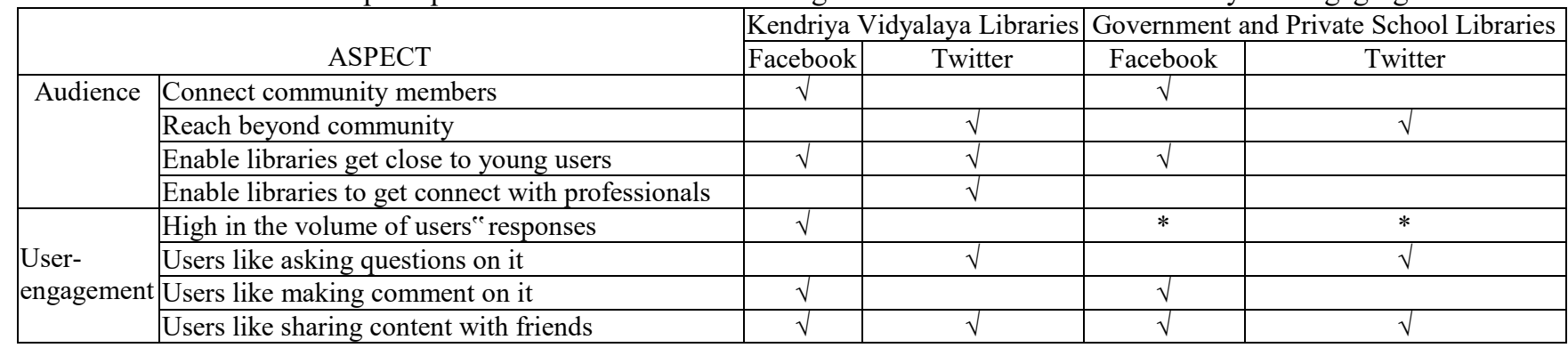

Note: *Since the librarians from Government and private school mainly used one social media, they were not able to compare the volume of users ${ }^{\text {ee }}$ responses on different social media justly.

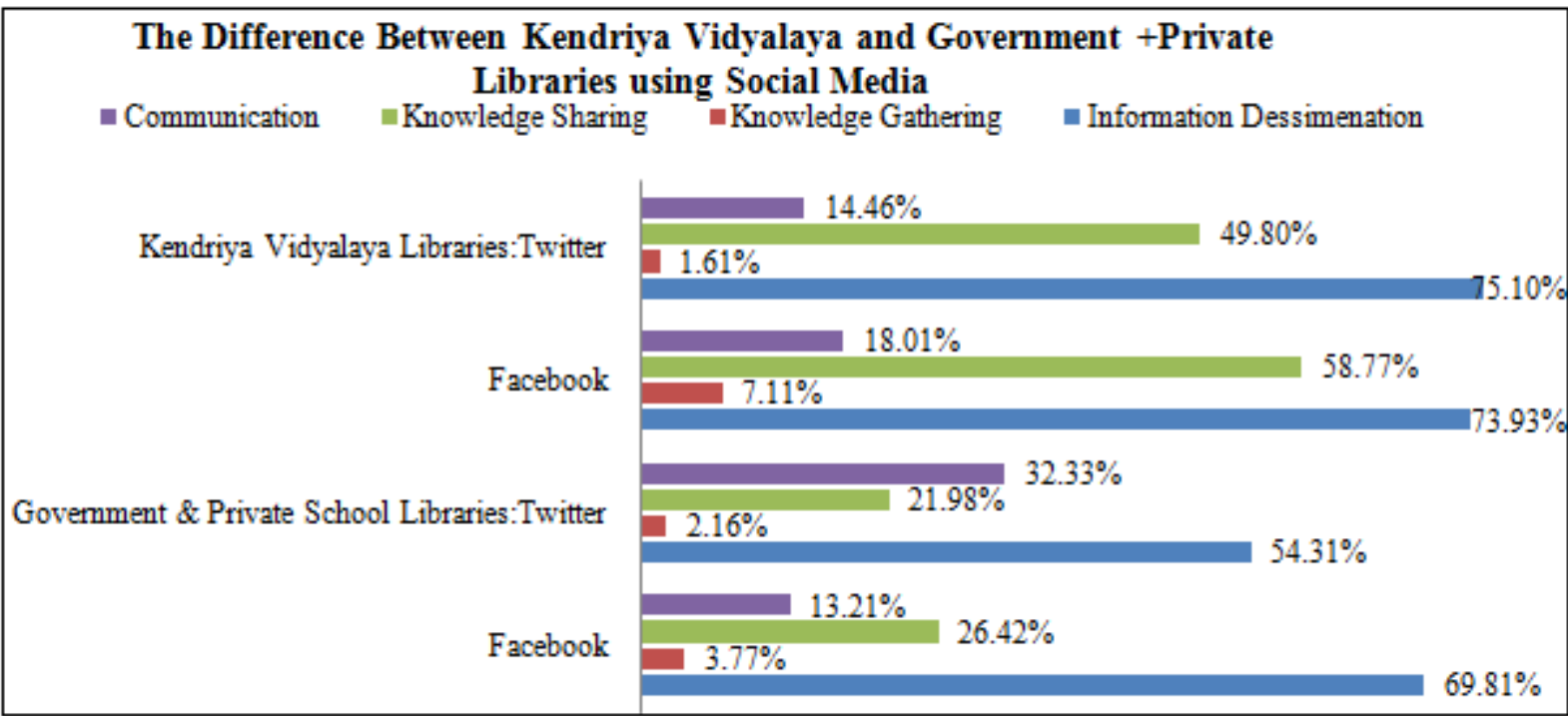

Figure 2: The differences between academic and public libraries in using Social Media

Note: The percentages mean the proportions of posts that carry a specific functionality. And since the functionalities are not mutually exclusive, the stacked bars here are not necessarily up to $100 \%$.

\section{Differences of between Kendriya Vidyalaya Libraries and Government + Private School libraries}

To find out how Kendriya Vidyalay Libraries and Government +Private libraries work out with social media respectively, MANOVA was applied on the sampled posts to explore the differences of user engagement on social media between Kendriya Vidyalay Libraries and Government +Private libraries. The variables included "library type", "region", and "Social Media". The result revealed Kendriya Vidyalaya libraries were better than its counterparts from Government and Private School Libraries in engaging users on their Social Media, It is observed that Government Schools has no library functioning.Automation of libraries use of Bar coding, scanner and library website and use of ICT is a thing of far away but physically no library is found in proper way. While Private school libraries were a much better than those Government School Libraries. When looking into different Social Media, for Kendriya School libraries, the mean of user responses was the highest on Facebook. For Government and Private School Libraries, Facebook too got highest means of user responses. To see a fuller picture of how Kendriya Vidyalaya libraries and Government +Private School libraries use Social Media respectively, the sampled posts were grouped by different attributes: regions, Social Media together with library types. Then the percentages of the four types of interactions were calculated for each group (see Figure 2). It could be observed from Figure 2 that Kendriya Vidyalaya libraries from Kendriya Vidyalaya Sangthan. Government and Private School Libraries did not carry out knowledge sharing as much as the counterparts from Kendriya Vidyalaya Libraries $(49.80 \%$ compared with $21.98 \%$ on Twitter-like tools, and $58.77 \%$ compared with $26.42 \%$ on Facebook). This gap in knowledge sharing could explain why Kendriya Vidyalaya libraries had higher user engagement than those of Government and Private School Libraries on their Social Media. Also, the figure showed that the percentage of communication was noticeable on Facebook, compared with Twitter. Its proportion was comparable with that of knowledge sharing, accounting for more than $30 \%$.

\section{Volume 4 Issue 11, November 2015}




\section{International Journal of Science and Research (IJSR) \\ ISSN (Online): 2319-7064 \\ Index Copernicus Value (2013): 6.14 | Impact Factor (2014): 5.611}

4 Although the statistics indicates that Kendriya Vidyalaya libraries attain more user responses than Government and Private School libraries on average, it is not necessary that Kenderiya Vidyalaya libraries are more successful in using social networking. The reason is that in our sample, Kendriya Vidyalaya libraries are of 29 Region of Kendriya Vidyalaya Sangthan ones, which serve larger users than Government and Private School libraries. And this fact can impact on the amounts of user responses. Hence, we do not compare Kendriya Vidyalay Libraries and Government + Private School libraries in this direct way.

Table 6: The differences of user engagement on Social Media between Kendriya Vidyalaya and Government+ Private School libraries

\begin{tabular}{|c|c|c|c|c|}
\hline Library Type & $\begin{array}{c}\text { Social } \\
\text { Media }\end{array}$ & $\begin{array}{c}\text { Mean } \pm \text { Std. } \\
\text { Error }\end{array}$ & F & Sig. \\
\hline $\begin{array}{c}\text { Kendriya } \\
\text { Vidyalaya Libraries }\end{array}$ & Facebook & $\mathbf{2 3 . 3 7 \pm 1 . 4 5}$ & & \\
\cline { 2 - 3 } Twitter & $8.34 \pm 1.38$ & 56.14 & $.000 *$ \\
$\begin{array}{c}\text { Government and } \\
\text { Private School } \\
\text { Libraries }\end{array}$ & Facebook & $11.30 \pm 2.04$ & & \\
\cline { 2 - 3 } & Twitter & $4.08 \pm 1.33$ & & \\
\hline
\end{tabular}

Note: The highest means are in bold; $* \mathrm{p}<0.001$

Table 7: The differences of user engagement between Kendriya Vidyalaya and Government+Private School libraries under different types of Interactions

\begin{tabular}{|l|l|c|c|c|}
\hline Library Type & \multicolumn{1}{|c|}{ Interaction } & $\begin{array}{c}\text { Mean } \pm \\
\text { Std. Error }\end{array}$ & $T$ & Sig. \\
\hline \multirow{2}{*}{$\begin{array}{l}\text { Kendriya } \\
\text { Vidyalaya }\end{array}$} & Knowledge Sharing & $3.41 \pm 0.74$ & 1.13 & 0288 \\
\cline { 2 - 5 } & Information Dissemination & $3.54 \pm 0.31$ & 2.51 & .114 \\
\cline { 2 - 5 } & Communication & $\mathbf{6 . 6 0} \pm \mathbf{0 . 6 1}$ & 9.95 & $.000^{*}$ \\
\cline { 2 - 5 } & Knowledge Gathering & $4.21 \pm 1.30$ & 0.05 & .825 \\
\hline $\begin{array}{l}\text { Government } \\
\text { and Private } \\
\text { School } \\
\text { Libraries }\end{array}$ & Knowledge Sharing & $\mathbf{2 2 . 5 2} \pm \mathbf{1 . 9 6}$ & 10.05 & $.000^{*}$ \\
\cline { 2 - 5 } & Information Dissemination & $15.91 \pm 1.69$ & 1.59 & .208 \\
\cline { 2 - 6 } & Communication & $11.70 \pm 1.77$ & 0.19 & .662 \\
\cline { 2 - 6 } & Knowledge Gathering & $18.10 \pm 4.74$ & 1.34 & .300 \\
\hline
\end{tabular}

Note: The highest means are in bold; $* \mathrm{p}<0.001$

Means of the number of user responses were also compared between posts of a certain interaction types (see Table 7).The null hypothesis is that "the means of user responses are not different between posts carrying certain type of interaction and those not carrying that type of interaction."The result showed that the capability of the different interactions in engaging users differs between Kendriya Vidyalaya Libraries and Government libraries. Table 6 showed that for Kendriya Vidyalaya libraries, the mean of user responses to the posts of knowledge sharing was the highest $(\mathrm{p}<0.001)$. But for Government and Private School libraries, knowledge sharing did not have the same effect. Rather, communication seems to have more leverage on engaging users on Prvate School libraries ${ }^{e c}$ Social Media. The mean of user responses to the posts of communication was the highest $(p<0.001)$. This result explained why the Government and Private School libraries on Twitter, who conducted significantly more communication than their counterparts on Facebook or Twitter, work best in engaging users (see Table 6).

\section{Discussion}

Our result indicates that users $^{\text {ee }}$ interest varies among different types of interactions. Knowledge sharing tends to be the most engaging. This result echoes the opinion about the important role of libraries in knowledge communities,Information dissemination is mediocre in engaging users, which is consistent with extant research. As for communication, overall, it is lower than knowledge sharing in the volume of user responses. But when it happens on Twitter, the Social Media that seems not very friendly to knowledge sharing, communication even surpasses knowledge sharing in engaging users. This finding implies that, when information organizations use Social Media to connect their users, there is a delicate balance between social network and mass communication. Moreover, according to our findings, knowledge gathering is very rare on librariese Social Media. This interaction is underused and underexplored at this stage. In our sample, most circumstances of knowledge gathering are online surveys, in which the freedom of expressions is limited. There are few cases in which librarians use Social Media to set up online forums where library users can express themselves freely. Hence, it is worthwhile practicing more experiments or explorations on this type of interaction.

Second, Facebook-like sites work differently from Twitter like sites, regarding interactions between libraries and users. The features of Facebook are supportive in connecting community, while the nature of Twitter is more of a newsfeeding tool, disseminating information from one to another, who do not need to be friends or acquaintances with each other. As shown in our findings, Facebook is efficient in knowledge sharing, and Twitter is effective in facilitating communication. To improve the efficiency of interactions on Social Media, librarians should make full use of these differences, and consider assigning or stressing different interactions to different Social Media. This coordination of different Social Media is also critical for solving the information overload problem. Among the four types of interactions, libraries use Social Media to carry out information dissemination the most frequently. News and announcements from libraries have dominated libraries ${ }^{\text {ee }}$ Social Media. Knowledge or communication could easily be buried. There is a risk that Social Media just act as libraries ${ }^{\text {ee }}$ another information feeding machine, sending content in one-way other than interacting with users. By dividing different types of interactions among different Social Media and defining policies specific for different Social Media, libraries can minimize risk exposure and alleviate the information overload problem on their Social Media.

Third, there are differences between Kendriya Vidyalaya and Government + Private School libraries when using Social Media to interact with library users. As indicated in our findings, Kendriya Vidyalaya libraries ${ }^{\text {ee }}$ users are more engaged with using Social Media to communicate with librarians. and in knowledge sharing. One-to-many knowledge sharing is not needed by many users. one-to-one communication, in which pertinent information or knowledge is provided, is more fitting in Kendriya Vidyalaya Students. As suggested by Kivran-Swaine and Naaman's study (2011), one-to-one communication, which carries personal messages, would enhance user engagement, but when the network is dense, it becomes costly for libraries to execute communication through Social Media. On the other hand, it also implies that libraries which

\section{Volume 4 Issue 11, November 2015}




\section{International Journal of Science and Research (IJSR) \\ ISSN (Online): 2319-7064}

Index Copernicus Value (2013): 6.14 | Impact Factor (2014): 5.611

provide services to small communities, could consider using Social Media to communicate with individual users. In this sense, compared with large libraries of Kendriya Vidyalaya, using Social Media to communicate with users is more effective for academic libraries, since they just serve the communities of Kendriya Vidyalaya. Hence, libraries can adjust their investment in different interactions, according to properties of their communities.

\section{Limitations}

This study measures user engagement in the number of user responses. The quality of user responses is not sufficiently studied. And the study relies heavily on the objective data from libraries ${ }^{\text {ee }}$ Social Media. Subjective data on how users expect libraries use Social Media is missing. Also, while the study focuses on the application of different Social Media, cultural factors are not delved into. And this would probably generate more meaningful theoretical results. Further studies can be improved by including user inputs on libraries "Social Media, surveying users"e opinions and exploring cultural aspects of applying Social Media. As to our sample, all the Kendriya Vidyalaya libraries are facilitated with ICT facilities. Therefore, the findings may not be applicable to all School libraries in India where still School Libraries are functioning in papers but on ground nothing is being done to establish libraries. More studies especially for School libraries in India are still needed.

\section{Conclusion}

The findings of this study refine the knowledge of how libraries can use Social Media to engage users efficiently, by exploring different interactions on libraries "e Social Media, different Social Media and the differences between Kendriya Vidyalaya and Government + Private School libraries in using those tools to engage users. These explorations and comparisons have revealed that the four types of interactions engage library uses differently. Knowledge sharing on Facebook can attract highest volume of user responses for libraries. In the meantime, communication is still the most engaging interaction on Twitter. There are necessities that libraries coordinate Social Media, to provide quality services and interact with users efficiently. Finally, this study also finds out that users ${ }^{\text {ee }}$ interest in using Social Media to interact with librarians is different between Kendriya Vidyalaya libraries and Government + Private School libraries. The findings imply that by taking the properties of their communities under consideration, libraries can improve the efficiency of their Social Media.

\section{Acknowledgments}

I am thankful to Kendriya Vidyalaya Librarians, Don Bosco Sr. Sec. School Lumding Librarian, Rly Sr. Sec Boys and Girls School Lumding Librarian, Prabnanda Sr. Sec School Lumding, and Headmasters of Government Schools for providing essential information regarding Libraries.

\section{References}

[1] Do you Facebook? Usage and applications of Facebook page among academic libraries in Malaysia. The International Information \& Library Review, 43(4), 239-249. Boyd, D.M., \& Ellison, N.B. (2007).

[2] Social network sites: Definition, history, and scholarship. Journal of Computer-Mediated Communication, 13(1), 210-230. Burkhardt, A. (2010). Social media: A guide for college and university libraries. College \& Research Libraries News, 71(1), 10-24.

[3] Burton, S., \& Soboleva, A. (2011). Interactive or reactive? Marketing with Twitter. Journal of Consumer Marketing, 28(7), 491-499.

[4] Cahill, K. (2009). Building a virtual branch at Vancouver Public Library using Web 2.0 tools. Program: electronic library and information systems, 43(2), 140-155.

[5] Casey, M., \& Savastinuk, L. (2006). Library 2.0: service for the next-generation library. Library Journal, 131(14), 40-42. Charnigo, L., \& Barnett-Ellis, P. (2007).

[6] Checking Out Facebook.com: The Impact of a Digital Trend on Academic Libraries. Information Technology and Libraries, 26(1), 23-34.

[7] Chen, D.Y.T., Maxwell, W., Chu, S.K.W., Li, W.Z.S., \& Tang, L.L.C. (2011).

[8] Interaction between libraries and library users on Facebook. Paper presented at the CITE Research Symposium 2011, The University of Hong Kong, Hong Kong. Chu, M., Meulemans, \& Nalani, Y. (2008).

[9] The Problems and Potential of MySpace and Facebook Usage in Academic Libraries. Internet Reference Services Quarterly, 13(1), 69-85. Chu, S.K.W., \& Du, H.S. (2012).

[10] Social networking tools for academic libraries. Journal of Librarianship and Information Science. Coyle, C., \& Vaughn, H. (2008). Social networking: Communication revolution or evolution? Bell Labs Technical Journal, 13(2), 13-18. Creswell, J.W. (2003).

[11] Mixed methods procedures: data collection procedures. In 2nd (Ed.), Research Design: qualitative, quantitative, and mixed methods approaches(pp. 219 220).

[12] California: Sage. Dalkir, K. (2011). Measuring the impact of social media: connection, communication and collaboration. In J. P. Girard \& J. L. Girard (Eds.), Social knowledge: using social media to know what you know (pp. 24-36).

[13] Hershey, PA: Information Science Reference. De Rosa, C., Cantrell, J., Havens, A., Hawk, J., Jenkins, L., Gauder, B., Cellentani, D. (2007).

[14] Sharing, privacy and trust in our networked world: A report to the OCLC Membership. Dublin, OH: OCLC Online Computer Library Center. Pempek, T.A., Yermolayeva, Y. A., \& Calvert, S. L. (2009).

[15] College students' social networking experiences on Facebook. Journal of Applied Developmental Psychology, 30, 227-238. Poynter, R. (2010). The handbook of online and social media research: tools and techniques for market researchers (pp. 163-260).

[16] Chichester, West Sussex, U.K.: Wiley. QS World University Rankings 2010. (2010), from 


\section{International Journal of Science and Research (IJSR) \\ ISSN (Online): 2319-7064 \\ Index Copernicus Value (2013): 6.14 | Impact Factor (2014): 5.611}

http://www.topuniversities.com/universityrankings/ world-university-rankings/2010 Ram, S., Anbu. K., J.P., \& Kataria, S. (2011).

[17] Responding to user's expectation in the library: innovative Web 2.0 applications at JUIT Library: A case study. Program: electronic library and information systems, 45(4), 452-469. Romero, N.L. (2011).

[18]ROI. Measuring the social media return on investment in a library. The Bottom Line: Managing Library Finances, 24(2), 145-151.

[19] Seonghee, K., \& Boryung, J. (2008). An analysis of faculty perceptions: Attitudes toward knowledge sharing and collaboration in an academic institution. Library \& Information Science Research, 30(4), 282290.

[20] Stuart, D. (2010). What Are Libraries Doing on Twitter? (Vol. 34). Wilton, CT, ETATS-UNIS: Online. $\mathrm{Xu}$, C., Ouyang, F., \& Chu, H. (2009). The Academic Library Meets Web 2.0: Applications and Implications. The Journal of Academic Librarianship, 35(4), 324331.

\section{APPENDIX: A Survey on Application of Social Media in Libraries}

Q1. Usefulness of Facebook and Twitter

Q1a. Please underline your choice regarding the level of usefulness of Facebook, Twitter, bases on this scale below: Scale: 1 - Not useful; 2 - A little bit useful; 3 -Somewhat useful; 4 - Useful; 5 - Very useful

\begin{tabular}{|c|c|c|c|}
\hline $\begin{array}{c}\text { Social } \\
\text { Media }\end{array}$ & $\begin{array}{c}\text { Enhance } \\
\text { Reference Services }\end{array}$ & $\begin{array}{c}\text { Help promote } \\
\text { Library Services }\end{array}$ & $\begin{array}{c}\text { Facilitate } \\
\text { Knowledge } \\
\text { Sharing }\end{array}$ \\
\hline Facebook & 12345 & 12345 & 12345 \\
\hline Twitter & 12345 & 12345 & 12345 \\
\hline
\end{tabular}

Q1b. For each response from the interviewee with a "4"or "5", ask why. (e.g., Would you tell us why you think using Facebook for internal purpose is useful to facilitate information sharing?)

Q1c. Are there other kinds of benefits for using Facebook, Twitter in your library?

Q2. Interactions (posts that attract lots of users ${ }^{\text {ee }}$ replies /comments)

Q2a. Would you tell me why this post attracts more replies / comments than the others?

Q2b. Between Facebook, Twitter, in your opinion which is more effective in stirring up interaction between librarians and library users?

Q3a. Does your library have any guideline(s) to decide what is appropriate for the library to post on Facebook or Twitter ?

Q3b. For libraries using both Facebook and Twitter, ask: Does your library have different guidelines for the 2 tools?

Q3c. Does your library have any guideline(s) for responding to library userse questions / comments / complaints on Facebook, Twitter ? (In terms of how soon the library will respond; what to respond; what not to respond; etc.)

Q4. Audience For library that has both Facebook \& Twitter profiles, ask: Do you have different target audiences in mind?
Q5. Only Facebook, Twitter, For library that uses only Facebook or Twitter,ask: Why does your library use only Facebook or Twitter?

Q6. What are the challenges and difficulties for implementing Facebook or Twitter in your library?

Q7. Do you have other comments about the use of Facebook, Twitter / Weibo in your library?

\section{Author Profile}

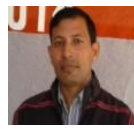

Anup Singh did B.A.M.A. Eng, Pol. Sc., B. Ed, BLIS, MLIS, M. Phil, UGC NET (LIS). He is Librarian, K.V.Nadaun, VPO+Tehsil:Nadaun, Distt: Hamirpur (H.P)782447, India 